Prace Literackie LVIII

Wrocław 2018

https://doi.org/10.19195/0079-4767.58.7

\author{
ANNA GIBASIEWICZ \\ ORCID: 0000-0002-9135-0879 \\ Wrocław
}

\title{
Teofil Nowosielski — dziewiętnastowieczny propagator polskiej historii i postaw patriotycznych w książkach dla dzieci
}

Teofil Nowosielski (1812-1888), dziewiętnastowieczny pisarz dla dzieci i dorosłych, pedagog i wychowawca, współzałożyciel warszawskich Sal Ochron przy Warszawskim Towarzystwie Dobroczynności, doskonale zdawał sobie sprawę, że nauczanie historii polskich dzieci w sytuacji utraconej wolności jest niezwykle ważne i konieczne. Dlatego w swej twórczości oferował, oprócz wielu innych, również książki o tematyce historycznej, pełniące często rolę kryptopodręczników z powodzeniem wykorzystywanych do nauczania domowego.

O tym, że nauczanie historii jest istotne, wiedzieli już myśliciele oświeceniowi, którzy opowiadali się zgodnie za potrzebą nauczania historii. Koncepcje filozofów, historyków, pedagogów zachodnioeuropejskich wywarły ogromny wpływ na polską myśl dydaktyczną. Niewątpliwie znaczący wpływ na rozwój oświaty i dydaktyki miał Stanisław Konarski, a także Adam Naruszewicz, którego poglądy zawarte w Memoriale względem pisania historii narodowej wywarły ogromny wpływ na nauczanie historii w szkołach Komisji Edukacji Narodowej. Według niego historia powinna odtwarzać autentyczną przeszłość, dzieje nie tylko polityczne, ale też ustrojowe, gospodarcze, wyznaniowe, oświatowe oraz obyczaje.

Z kolei Grzegorz Piramowicz uważał, że historia powinna wychowywać do patriotyzmu i służby obywatelskiej, wpływać na kształcenie dyplomatów i urzędników. Ostatecznie Komisja Edukacji Narodowej wypracowała stanowisko, że historia jako nauka moralna, gromadząca doświadczenia przodków, powinna zajmować należne jej miejsce w kształceniu młodzieży, tak aby wiedza, której dostarcza, była należycie wykorzystywana przez kolejne pokolenia.

Upadek powstania listopadowego pogorszył sytuację polityczną kraju. Zamknięto Uniwersytet Warszawski i Towarzystwo Przyjaciół Nauk, wywieziono najcenniejsze zbiory polityczne, zlikwidowano mnóstwo periodyków, zaostrzono cenzurę. Wielu twórców w obawie przed represjami wyjechało za granicę. Ca- 
rat bezwzględnie tłumił jakiekolwiek idee narodowej tożsamości i niepodległości Polaków ${ }^{1}$.

W sytuacji, kiedy poszukiwano książek o tematyce patriotycznej, dużą popularność zyskały Śpiewy historyczne (1816) Juliana Ursyna Niemcewicza. Równie popularny stał się Pielgrzym w Dobromilu (1819) Izabeli Czartoryskiej i Wieczory pod lipa (1845) Lucjana Siemieńskiego. Autorzy tych utworów nie zawsze liczyli się z prawdą historyczną, nieraz mieszali fakty z legendą ${ }^{2}$. Szczególnie wiele niedociągnięć zarzucano Czartoryskiej. Joachim Lelewel w „Pamiętniku Literackim” pisał o Pielgrzymie w Dobromilu, że mimo iż książka ma wiele plusów, mianowicie: dydaktyka, wychowanie moralne, patriotyzm, prosty sposób przekazu, język stylizowany na wiejski, to jest w niej także utrwalone błędne przedstawienie polityki Władysława Jagiełł, Władysława Łokietka, Batorego czy Wazów. Lelewel zarzucał również Czartoryskiej rozbieżności pomiędzy legendami o św. Wojciechu, św. Kunegundzie a interpretacją zawartą w książce ${ }^{3}$. Mimo wszystko wymienione książki ze względu na walory dydaktyczno-literackie czytane były masowo, głównie przez młodzież, która poznawała z nich dzieje ojczyste i uczyła się szacunku dla wielkich tradycji narodowych.

Oświata cesarstwa wychodziła z założenia, że powszechny dostęp do szkolnictwa polskiego jest szkodliwy ze względów politycznych, dlatego zaczęto je bardzo mocno ograniczać. Zredukowano naukę w szkolnictwie średnim typu humanistycznego. Nie dopuszczano młodzieży z klas niższych do gimnazjów, utrudniano wyjazdy na studia zagraniczne. Od 1840 roku zaczęto zamykać gimnazja filologiczne, a wprowadzać gimnazja realne, starając się w ten sposób odciągnąc młodzież od nauk społecznych, pogłębiających postawy patriotyczne. W 1839 roku utworzono Warszawski Okręg Naukowy, bezpośrednio podporządkowany Ministerstwu Oświaty w Petersburgu. Kurator generalny Mikołaj Okuniew dążył do tego, by jak najwięcej przedmiotów wykładano w języku rosyjskim. Wzmacniano ponadto dozór policyjny nad uczniami.

W 1833 roku przeprowadzono reformę szkół średnich, w wyniku której młody Polak po skończonej nauce miał być przeświadczony o tym, że najlepiej być wiernym poddanym cara Mikołaja I. Stopniowo wycofywano i zaprzestano wznawiania polskich podręczników do nauczania historii polskiej. Od 1840 roku po nowej reformie w klasach I-IV rozporządzono nauczanie tylko historii powszechnej oraz rosyjskiej. Dzieje Polski usunięto również z siedmioletniego gimnazjum filologicznego. Mimo tego historia Polski była wykładana, tylko nie wszędzie, choć robiono to często łącznie z dziejami Rosji. Od 1843 roku nauczanie historii Polski w Królestwie Polskim prowadzone było według skrajnie pesymistycznego

${ }^{1}$ J. Maternicki, Dydaktyka historyczna w Polsce 1773-1918, Warszawa 1974, s. 24, 26-27, 60.

2 Ibidem.

3 J. Lelelwel, Pielgrzyma w Dobromilu, czyli nauk wiejskich rozbiór, z uwagami nad stanem wiejskim w Polszcze i ulepszeniem oświaty jego, „Pamiętnik Warszawski” 14, 1819, s. 324, 326-327. 
podręcznika Pawliszczewa, który podkreślał bezrząd i słabość Polski samej proszącej się o rozbiór.

Sporo uwagi nauczaniu historii poświęcał Eweryst Estkowski. Według niego historia powinna ugruntowywać w młodzieży miłość do ojczyzny. Za najlepszy podręcznik historii Polski uznał Wieczory pod lipa Lucjana Siemieńskigo. Zalecał również dzieła Joachima Lelewela, Maurycego Mochnackiego, Kazimierza Władysława Wójcickiego.

Niemały wpływ na rozwój nauczania historii od lat czterdziestych XIX wieku miał Bronisław Trentowski, który w Chowannie wyłożył poglądy na nauczanie historii. Uważał, że należy ją zaczynać od pokazywania dzieciom biografii wybitnych postaci ${ }^{4}$, co jak najbardziej robiono w kryptopodręcznikach. Podobnie czynił Teofil Nowosielski. Trentowski uważał również, że historia odgrywa także rolę wychowania religijnego, co też było widać w podręcznikach do nauczania domowego, w których podkreślano przymioty duchowe sławnych postaci, na przykład świętej Jadwigi. Ponadto Trentowski kładł nacisk na patriotyzm, zalecał opowiadanie dzieciom o cnotach pradziadów, aby nauczyły się ich kochać, a młodzieży pokazywanie ich błędów, by zapobiec popełnianiu podobnych. Postulaty te były realizowane jedynie poza oficjalnym obiegiem szkolnictwa, ponieważ w szkołach podległych zaborcom było to niemożliwe 5 .

W tych trudnych warunkach rodziła się potrzeba nauczania domowego, początkowo dostępnego tylko dla szlachty i arystokracji oraz bogatego mieszczaństwa, dopiero stopniowo obejmującego chłopów i proletariat ${ }^{6}$. Utrwalanie podziałów społecznych krytykował Joachim Lelewel w artykule zamieszczonym w „Pamiętniku Warszawskim”, omawiającym Pielgrzyma w Dobromilu Izabeli Czartoryskiej. Zarzucał autorce namawianie do pozostawania w stanie chłopskim i potępianie przez nią chęci jego porzucenia ${ }^{7}$.

Teofil Nowosielski, tworząc podręczniki do nauczania domowego, wpisał się w ten ogólnonarodowy nurt trwający przez cały okres zaborów, szczególnie nasilony w drugiej połowie XIX wieku. Jego podręczniki odegrały swoistą rolę w edukacji. Stanowiły realną pomoc metodyczno-naukową zarówno w placówkach opiekuńczo-wychowawczych, jak i w prywatnych domach ${ }^{8}$.

Pozytywne nastawienie do edukacji domowej po upadku Rzeczypospolitej wynikało, jak wcześniej wspomniano, z niechęci do szkół zaborczych, których było bardzo mało, a także z przekonania, że edukacja domowa jest lepsza, ponieważ dziecko, wychowując się w rodzinie, nie jest od niej odseparowywane. Po powsta-

\footnotetext{
${ }^{4}$ J. Maternicki, op. cit.

${ }^{5}$ Ibidem.

${ }^{6}$ R. Waksmund, Pokój dziadunia, wzory edukacji domowej w XIX-wiecznej literaturze dla dzieci i młodzieży, [w:] Nauczanie domowe dzieci polskich od XVIII do XX wieku: zbiór studiów, red. K. Jakubiak, A. Winiarz, Bydgoszcz 2004, s. 50-51.
}

7 J. Lelelwel, op. cit., s. 321.

${ }^{8}$ W. Bobrowska-Nowak, Historia wychowania przedszkolnego, Warszawa 1978, s. 60. 
niu listopadowym zagadnienie edukacji domowej stało się także przedmiotem dyskusji na emigracji. Głos w tej sprawie zabrał Stefan Witwicki sprzeciwiający się oddawaniu dzieci polskich do szkół zaborczych czy też sprowadzanym z zagranicy guwernantkom. Realizowaną przez obcokrajowców edukację uważał za kosmopolityczną i wynaradawiającą. Apelował do matek-Polek i matek-chrześcijanek, aby wpajały dzieciom miłość do języka ojczystego ${ }^{9}$.

Rządy, które pozbawiły Polskę niepodległości, w krótkim czasie narzuciły obcy system szkolny, wrogi polskim ideałom, podporządkowujący szkołę celom politycznym, wypaczający charaktery i przytępiający umysły młodzieży. W takich warunkach nauczanie domowe przybrało postać nigdzie dotąd niespotykaną. Stało się ucieczką dla tych wszystkich, którzy chcieli uchronić swoje dzieci od zgubnych wpływów szkoły rządowej i przeistoczyło się w system najbardziej narodowy i najbardziej postępowy, na jaki było stać wtedy Polaków w tak opłakanych warunkach ${ }^{10}$.

Teofil Nowosielski jako autor podręczników do nauczania domowego niewątpliwie wpisywał się w ogólnonarodowy nurt zdobywania wiedzy poza oficjalnym szkolnictwem rządowym, realizującym antypolski program. Dzięki zamieszczanym w nich informacjom historycznym dawał dzieciom możliwość przyswojenia sobie podstawowej wiedzy na temat dziejów Polski, jej królów, władców, a także postaci legendarnych. Mali uczniowie mogli również zaznajomić się z podstawowymi wiadomościami geograficznymi dotyczącymi Polski i przejść podstawowy kurs czytania, pisania i liczenia.

Pierwszym podręcznikiem do nauczania domowego, w którym zamieścił krótkie wiadomości historyczne, a drugim z kolei, był Towarzysz domowy pilnych dzieci (1846). Można powiedzieć, że książka ta była wstępem do tego, by w kolejnych opowiadać polskim dzieciom coraz więcej o historii swojego narodu. W Towarzyszu pilnych dzieci autor zamieścił jedynie wiadomości geograficzne poświęcone omówieniu najbardziej znaczących państw ówczesnej Europy, począwszy od Cesarstwa Rosyjskiego, w którego skład wchodziła Polska. Przy okazji opisu Krakowa wspomina też o Prusach i Austrii, nie tłumacząc jednak rozbioru Polski. W opisie Warszawy podkreśla kilka wątków polskich, mówi o kolumnie Zygmunta i pomniku Kopernika. Innym państwom Nowosielski poświęca znacznie mniej miejsca, sygnalizując jedynie ich istnienie. Następnie prezentuje historię powszechną, a po niej historię naturalną.

Podręcznik ten ze względu na bogatą i różnorodną tematykę zawiera w sobie cechy zarówno elementarza, jak i encyklopedii oraz słownika, a także książki popularnonaukowej. Był on wielokrotnie wznawiany. Orgelbrand w swoich wy-

${ }^{9}$ S. Witwicki, Wieczory pielgrzyma. Rozmaitości moralne, literackie i polityczne, t. 2, Lipsk 1866, s. 99-101.

${ }^{10}$ A. Szycówna, Nauczanie domowe, [w:] Encyklopedia wychowawcza, red. R. Plenkiewicza, Warszawa 1890, t. 6, s. 530-537; cyt. za: Źródła do dziejów nauczania domowego dzieci polskich w XIX i początku XX wieku z bibliografia adnotowana pamiętników i wyborem literatury pedagogicznej, red. K. Jakubiak et al., Bydgoszcz 2005, s. 30, 32. 
powiedziach na łamach dziewiętnastowiecznej prasy reklamował podręcznik, dowodząc, że służy on nie tylko do poznawania liter i początkowego czytania, lecz stanowi również przewodnik po innych dziedzinach nauki. Niewątpliwie ze względu na poprawność merytoryczną i wielowątkowość poruszanych tematów był cenną pozycją wśród podręczników przeznaczonych do domowego nauczania, które często porównywano do encyklopedii.

Następnym podręcznikiem dla dzieci, który wyszedł spod pióra Nowosielskiego, był Ilustrowany abecadlnik historyczny dla dzieci polskich ${ }^{11}$ (1862), uznany za najlepiej opracowany i najstaranniej wydany abecadlnik historyczny ${ }^{12}$. Słusznie Iwona Michalska pisała, że z powodzeniem konkurował on z innymi tego typu podręcznikami, na przykład z Abecadlnikiem z historii polskiej Ludwika Anczyca czy też Abecadlnikiem w wierszykach dla dzieci polskich Władysława Bełzy ${ }^{13}$.

Książka Nowosielskiego zaczyna się od nauki czytania i zaprezentowania alfabetu. Potem są krótkie nauczki moralne o tym, jak należy zachować się w codziennych sytuacjach i wybrane modlitwy. Następnie opowiedziane są dzieje Polski, nazwane przez autora „obrazkami z historii polskiej prozą"14. Są to wybrane zagadnienia z historii państwa. Obrazki owe przedstawiają legendarnego Krakusa i Wandę, Leszka II, Władysława Łokietka, Stefana Batorego, Jana III Sobieskiego, Kazimierza Wielkiego, a także wybitne postaci, takie jak: Zawisza Czarny, Jan Kochanowski, Stefan Czarniecki, Jan Długosz czy Stańczyk. Owe krótkie czytanki były elementem odróżniającym Ilustrowany abecadlnik od Towarzysza pilnych dzieci. Nowosielski zamieścił w książeczce także patriotyczne wierszyki, między innymi o królowej Jadwidze, Kazimierzu Wielkim, Władysławie Łokietku, Janie Zamoyskim, Zbigniewie Oleśnickim, Stefanie Potockim, Zygmuncie Auguście i umierającej Barbarze Radziwiłłównie, a także o śmierci Władysława Warneńczyka, księciu Witoldzie i Zygmuncie I, opatrzone pięknymi rycinami wykonanymi przez znakomitego malarza Wojciecha Gersona ${ }^{15}$.

Opowiedzenie części historii wierszem było dużym urozmaiceniem i uprzyjemnieniem przyswajania podawanych wiadomości przez dzieci. Niewątpliwie Nowosielski realizował w ten sposób postulat popularyzowania wiedzy historycznej. Została tu ona przedstawiona w sposób chronologiczny i uporządkowany, a jednocześnie syntetyczny, dostosowany do wieku małego odbiorcy. Jeśli chodzi o wiadomości geograficzne, tym razem Polskę opisał jako Królestwo Polskie gra-

${ }^{11}$ Książka ukazała się nakładem Księgarni Aleksandra Nowoleckiego, przy ul. Senatorskiej i Krakowskiego Przedmieścia, nr 457, naprzeciwko kolumny Zygmunta. T. Nowosielski, Ilustrowany abecadlnik historyczny dla dzieci polskich, Warszawa 1862.

${ }^{12}$ F. Pilarczyk, Elementarze polskie od ich XVI-wiecznych początków do II wojny światowej. Próba monografii księgoznawczej, Zielona Góra 2003, s. 98.

13 I. Michalska, Przyczynki Teofila Nowosielskiego do edukacji domowej, [w:] Nauczanie domowe dzieci polskich od XVIII do XX wieku. Zbiór studiów, red. K. Jakubiak, A. Winiarz, Bydgoszcz 2004, s. 64-65.

14 T. Nowosielski, op. cit., s. 34.

15 Książki dla dzieci, „Przyjaciel Dzieci” 1862, nr 3, s. 44. 
niczące z Prusami, Rosją i Austrią i omówił krótko najważniejsze miasta Królestwa, między innymi: Warszawę, Łódź, Kalisz, Częstochowę, Radom, Sandomierz. Autor skupił się tu przede wszystkim na historii Polski, dlatego nie zawarł tam, tak jak w Towarzyszu pilnych dzieci, historii powszechnej. Również geografia została tu ograniczona do Polski, a więc akcent tego podręcznika był zdecydowanie bardziej patriotyczny. Ze względu na swe walory zarówno edukacyjne, jak i wychowawcze, a także edytorskie polecany był on do nauczania domowego.

Kolejnym podręcznikiem do nauczania domowego, napisanym przez Nowosielskiego, był wydany po raz pierwszy w 1876 roku Podarek dla grzecznych i pilnych dzieci. Książeczka abecadłowa ${ }^{16}$. Czwarty elementarz popularnego autora dla dzieci wykazuje wiele podobieństw do Świata dziecięcego i Towarzysza pilnych dzieci. Natomiast w przeciwieństwie do Ilustrownego abecadlnika historycznego nie zawiera treści historyczno-patriotycznych oprócz przedstawienia zarysu sylwetek czterech zasłużonych dla Polski postaci, mianowicie: księdza Jakuba Falkowskiego, Stanisława Jachowicza, Mikołaja Kopernika i Kazimierza Brodzińskiego.

Następnym podręcznikiem do nauczania domowego, wydanym w dwóch tomikach, były Dzieje Polski w obrazkach ${ }^{17}$, którego współautorką była Maria Ilnicka, oraz Historia polska dla dzieci treściwie napisana, ozdobiona w tekście dwunastoma portretami znakomitszych królów polskich ${ }^{18}$. Tytuły te wskazują wyraźnie na charakter książek, podkreślając, że są to przede wszystkim podręczniki do nauki historii Polski, napisane wyczerpująco, odpowiednio do dziecięcego wieku, a także ozdobione ilustracjami mającymi na celu wzbogacenie odbioru przekazywanych treści.

W dobie rozbiorów zdawano sobie sprawę, że nauczanie historii, zapoznanie dzieci i młodzieży z postaciami bohaterów narodowych miało szczególne znaczenie w kształtowaniu postaw patriotycznych młodych obywateli. Dlatego też książki historyczne były wysoko oceniane przez pedagogów i krytyków literackich. Nowosielski, opracowując takie podręczniki, wpisywał się w ogólnonarodowy nurt edukacji historycznej, trwający przez cały XIX wiek, szczególnie nasilony w drugiej połowie tego stulecia.

O Dziejach Polski w obrazkach pisał między innymi w swoim Katalogu krytycznym Adolf Dygasiński. Twierdził on, że to bardzo starannie wydana książeczka. Pozytywnie wyrażał się również o samej jej treści, ponieważ opowiadała o dziejach

16 T. Nowosielski, Podarek dla grzecznych i pilnych dzieci. Ksiązeczka abecadłowa zawierająca poczatki nauki czytania oraz Światek dziecięcy w powiastkach, bajeczkach, piosenkach przy dołaczeniu krótkiej wiadomości o rzeczach pożytecznych i ludziach zasłużonych, Warszawa 1883, karta tytułowa.

17 T. Nowosielski, M. Ilnicka, Dzieje Polski w obrazkach, wierszem i proza dla dzieci napisane z dodaniem historii i geografii dawnej Polski treściwie zebranej, z licznymi drzeworytami w tekście rysunku pp. Fałata, Gersona, Kossaka, Krzesza, Pilatego, Tegazza, Kraków 1882.

${ }_{18}$ T. Nowosielski, Historia polska dla dzieci treściwie napisana, ozdobiona w tekście dwunastoma portretami znakomitszych królów polskich, Kraków 1882. 
Polski, począwszy od historii mitycznych o Krakusie, Wandzie, Piaście, a skończywszy na postaci Kościuszki. Zachęcające było według niego to, że cały materiał został ułożony chronologicznie w krótkich, interesujących biografiach pisanych prozą oraz wierszem. „Historyk mógłby wtrącić swoje veto tu i ówdzie — pisał Dygasiński — [ale] my polecamy książkę, szczególnie gwoli pożytku dziatwy; jest bowiem lepsza, daleko lepsza nawet od wielu innych tej samej treści"19.

Zarówno Dzieje Polski w obrazkach, jak i Historia Polski dla dzieci treściwie napisana przedstawiają władców narodu w formie pocztu. Według Magdaleny Joncy przedstawianie dziejów państwa, życiorysów książąt i królów polskich $\mathrm{w}$ formie pocztu zostało usankcjonowane niezwykle popularną w całym XIX wieku praktyką zapoczątkowaną przez Niemcewicza ${ }^{20}$. Wypływało to z patriotycznego posłannictwa oświaty $\mathrm{w}$ okresie porozbiorowym, zamanifestowanego działalnością Warszawskiego Towarzystwa Przyjaciół Nauk ${ }^{21}$.

Ostatnim podręcznikiem do nauczania domowego autorstwa Nowosielskiego był drugi tomik Skarbca polskiego, czyli wspomniana Historia Polska dla dzieci treściwie napisana. Tym, co odróżnia go od pierwszego tomiku, są zawarte w nim wiadomości geograficzne dotyczące Wielkopolski, Małopolski i Wielkiego Księstwa Litewskiego z dokładnym omówieniem poszczególnych województw oraz „,chronologiczny porządek panujących królów i książąt polskich z wyszczególnieniem znaczniejszych wojowników, hetmanów i uczonych mężów"22. Nie ma w nim natomiast dziejów legendarnych, które z kolei znalazły się zarówno w pierwszym tomiku Skarbca, jak i w Ilustrowanym abecadlniku. Obrazy rodzimej przestrzeni, opisy ojczystych krajobrazów pozostawały w bezpośrednim związku z edukacją patriotyczną. Nurt ten zapoczątkowała Klementyna z Tańskich Hoffmanowa, zamieszczając w redagowanym przez siebie czasopiśmie „Rozrywki dla Dzieci”, redagowanym w latach 1824-1828, cykl artykułów krajoznawczych Opis pierwszej (drugiej, trzeciej itd.) w naszym kraju przejażdzki Anielce Ł przypisany. Wędrówka biegła trasą wspomnień narodowych ${ }^{23}$.

Historia Polska została wydana, podobnie jak Dzieje Polski, w 1882 roku i siedem lat później ujęta w spisie książek Jana Śliwki, w dziale książek zakazanych, ponieważ zawierała „uczucia moralne, patriotyczne i dynastyjne ${ }^{24}$, a więc mogła stanowić potencjalne zagrożenie $\mathrm{w}$ walce $\mathrm{z}$ wynaradawiającymi działaniami zaborcy. Istotnie, spośród wszystkich dotychczasowych podręczników wydanych przez Nowosielskiego, ten odznaczał się najmocniej akcentowanymi

19 A. Dygasiński, Krytyczny katalog książek dla dzieci i młodzieży, Warszawa 1884, s. 39.

${ }^{20}$ M. Jonca, Kraków królowej Jadwigi w wybranych utworach dla dzieci i młodzieży XIX-XX wieku, [w:] Kraków mityczny. Motywy, wątki, obrazy w utworach dla dzieci i młodzieży, red. A. Baluch, M. Chrobak, M. Rogoż, Kraków 2009, s. 61.

${ }^{21}$ R. Waksmund, Literatura pokoju dziecinnego, Warszawa 1986, s. 75.

22 T. Nowosielski, Historia Polska..., s. 1-5.

${ }^{23}$ R. Waksmund, Literatura pokoju..., s. 87-88.

24 J. Śliwka, Spis ksiażek poleconych i zakazanych przez Wysoka c. k. Radę Szkolna Krajowa, Cieszyn 1899, s. 99. 
treściami patriotycznymi i ze względu na przekazaną w nim lekcję historii wykazywał największe podobieństwo do Dziejów Polski w obrazkach oraz Ilustrowanego abecadlnika. Autor dosyć dokładnie prezentuje w nim, obok historii dawnej, wykład dotyczący utraty niepodległości oraz całej historii zniewolenia narodu, począwszy od wojen napoleońskich, do czasów mu współczesnych. Ukazana tutaj najnowsza historia Polski pod zaborami jest tym, co odróżnia elementarz od wszystkich pozostałych.

Książeczka napisana jest, podobnie jak wszystkie wcześniejsze podręczniki Nowosielskiego, w bardzo przystępny sposób i stanowi streszczenie historii Polski. Jest także materiałem do przypomnienia sobie geografii historycznej, ponieważ zostały w niej omówione wszystkie województwa i większe regiony dawnej Polski. Stanowiło to świetny materiał do nauki. Bardzo ciekawym pomysłem było pokazanie, obok królów i wojowników, sylwetek naukowców. Przekazywanie wiedzy w ten sposób ułatwiało wyobrażenie o danym okresie, pozwalało na wyrobienie sobie przez dziecko całościowego obrazu państwa polskiego oraz na łączenie poszczególnych elementów historii w logiczną całość i związek przyczynowo-skutkowy. Ponadto taka prezentacja dziejów narodu wzbudzała w uczniu patriotyzm i umacniała poczucie więzi ze swoim krajem.

\section{Bibliografia}

\section{Literatura podmiotu}

Nowosielski T., Historia polska dla dzieci treściwie napisana, ozdobiona w tekście dwunastoma portretami znakomitszych królów polskich, Kraków 1882.

Nowosielski T., Ilustrowany abecadlnik historyczny dla dzieci polskich, Warszawa 1862.

Nowosielski T., Król Bolesław Chrobry, „Nasz Głos” 1927, nr 10.

Nowosielski T., Podarek dla grzecznych i pilnych dzieci. Ksiażeczka abecadłowa zawierajaca początki nauki czytania oraz Światek dziecięcy w powiastkach, bajeczkach, piosenkach przy dotączeniu krótkiej wiadomości o rzeczach pożytecznych i ludziach zastużonych, Warszawa 1883.

Nowosielski T., Ilnicka M., Dzieje Polski w obrazkach, wierszem i proza dla dzieci napisane z dodaniem historii i geografii dawnej Polski treściwie zebranej, z licznymi drzeworytami w tekście rysunku pp. Fałata, Gersona, Kossaka, Krzesza, Pilatego, Tegazza, Kraków 1882.

\section{Literatura przedmiotu}

Bobrowska-Nowak W., Historia wychowania przedszkolnego, Warszawa 1978.

Dygasiński A., Krytyczny katalog książek dla dzieci i młodzieży, Warszawa 1884.

Jonca M., Kraków królowej Jadwigi w wybranych utworach dla dzieci i młodzieży XIX-XX wieku,

[w:] Kraków mityczny. Motywy, wątki, obrazy w utworach dla dzieci i młodzieży, red. A. Baluch, M. Chrobak, M. Rogoż, Kraków 2009.

Jonca M., Królowa Jadwiga. Szkice do portretu literackiego, Wrocław 2013.

Justus, Współczesne autorki polskie. Sylwetki literackie. Maria Ilnicka, „Rola” 1886, nr 35.

Książki dla dzieci, „Przyjaciel Dzieci” 1862, nr 3.

Lelelwel J., Pielgrzyma w Dobromilu, czyli nauk wiejskich rozbiór, z uwagami nad stanem wiejskim w Polszcze i ulepszeniem oświaty jego, „Pamiętnik Warszawski” 14, 1819. 
Maternicki J., Dydaktyka historyczna w Polsce 1773-1918, Warszawa 1974.

Michalska I., Przyczynki Teofila Nowosielskiego do edukacji domowej, [w:] Nauczanie domowe dzieci polskich od XVIII do XX wieku. Zbiór studiów, red. K. Jakubiak, A. Winiarz, Bydgoszcz 2004.

Nowosielski Teofil Stanisław, [w:] K. Estreicher, Bibliografia polska XIX stulecia, t. 3, Kraków 1876.

Nowosielski Teofil Stanisław, [w:] Nowy Korbut, t. 8, oprac. I. Śliwińska, S. Stupkiewicz, Warszawa 1969.

Nawrot-Borowska M., Nauczanie domowe na ziemiach polskich w II polowie XIX i początkach XX wieku - zapatrywania teoretyczne i praktyka, Bydgoszcz 2011.

Nowicki W., Co dać dziecku na gwiazdkę, Warszawa 1886.

Pilarczyk F., Elementarze polskie od ich XVI-wiecznych początków do II wojny światowej. Próba monografii księgoznawczej, Zielona Góra 2003.

Szycówna A., Nauczanie domowe, [w:] Encyklopedia wychowawcza, red. R. Plenkiewicza, Warszawa 1890, t. 6, s. 530-537; cyt. za: Źródła do dziejów nauczania domowego dzieci polskich w XIX i poczatku XX wieku z bibliografia adnotowana pamiętników $i$ wyborem literatury pedagogicznej, red. K. Jakubiak, G. Karłowska, M. Nawrot, A. Winiarz, Bydgoszcz 2005.

Śliwka J., Spis książek poleconych i zakazanych przez Wysoka c. k. Radę Szkolna Krajowa, Cieszyn 1899.

Waksmund R., Literatura pokoju dziecinnego, Warszawa 1986.

Waksmund R., Pokój dziadunia, wzory edukacji domowej w XIX-wiecznej literaturze dla dzieci i młodzieży, [w:] Nauczanie domowe dzieci polskich od XVIII do XX wieku: zbiór studiów, red. K. Jakubiak, A. Winiarz, Bydgoszcz 2004.

Winiarz A., Nauczanie domowe dzieci polskich $w$ dobie niewoli narodowej (1795-1918), [w:] Nauczanie domowe dzieci polskich od XVIII do XX wieku: zbiór studiów, red. K. Jakubiak, A. Winiarz, Bydgoszcz 2004.

Witwicki S., Wieczory pielgrzyma. Rozmaitości moralne, literackie i polityczne, t. 2, Lipsk 1866.

\section{Teofil Nowosielski - 19th-century propagator of Polish history and patriotic attitudes in children's books}

Summary

The goal of the article was to present Teofil Nowosielski's homeschooling textbooks for teaching historical and patriotic topics. The author also discusses the education system against the historical, political and moral background of 19th-century Poland.

Keywords: textbooks for home teaching, history, patriotism, education system, 19th century, Poland, partitions 